\title{
Gender Differences in the Relationship Between Household Position and Health in Twelve European Countries: Are They Associated with the Value Climate?
}

\author{
Gabriele Doblhammer and Jordi Gumà
}

\section{Introduction}

John Donne's (1572-1631) words "No man is an island" form the core of this study of household arrangement and health. The household is the main social entity at the meso-level; it is where men and women decide about their involvement in employment, paid and unpaid work, and caring responsibilities. These decisions are firmly rooted in the macro-level defined by the type of welfare state, which regulates state provisions, tax regimes, transfers to family members, and the opportunity of employment and associated conditions such as flexible and family friendly working arrangements (Boje 2007). The institutional context defines the extent to which the state supports economic independence between the partners and provides formal care for children and the elderly. Decisions are also rooted in prevailing individual values and social norms, concerning family formation, work, and care, all of which influence the climate of values which governs behavior during the social life course and influences the perception and experience of decisions made, such as forming a partnership by cohabiting or marrying, or having children in or outside of marriage. Gender roles define the extent to which deviations from the gendered division of work are feasible and socially accepted (Sayer and Bianchi 2000; Cooke and Gash 2010). Although there appears to be a convergence of gender roles within the household, this process is still unfinished (McDonald 2000;

\footnotetext{
G. Doblhammer ( $\bowtie)$

Institute for Sociology and Demography, University of Rostock,

Rostock, Germany

e-mail: gabriele.doblhammer@uni-rostock.de

J. Gumà

Department of Political and Social Sciences, University Pompeu Fabra,

Barcelona, Spain

e-mail: jordi.guma@upf.edu

(C) The Author(s) 2018

G. Doblhammer and J. Gumà (eds.), A Demographic Perspective on Gender,

Family and Health in Europe, https://doi.org/10.1007/978-3-319-72356-3_6
} 
Puur et al. 2008), and there is a lack of adaptation between the demographic behavior of partnership/family formation and the distribution of labor within the family. These macro-level factors must be taken into account when exploring the gendered association between household arrangements and individual health in different countries.

The most studied factors of health are located at the micro-level, the most prominent of which are related to social inequality in terms of education, income, and employment status (Marmot and Wilkinson 1999), life style (see e.g. von der Lippe and Rattay in this volume), and marital status (Waite 1995; Lillard and Waite 1995; Lillard and Panis 1996; Brockmann and Klein 2004; Martikainen et al. 2005). More recently the concept of marital status has expanded to include household arrangements at the meso-level which compile information about the interplay of individuals with other family members within the context of the same household (see also publications from the "Families And Societies" project). Members of a household share the same social and economic situation (Cherlin 2000; Stevenson and Wolfers 2007), and they have to negotiate their division of paid and unpaid work (Hughes and Waite 2002). Micro-level factors such as education and income, however, not only directly impact health but also shape the gender relationships in a household. In many countries women now outnumber men in terms of higher education (Vincent-Lancrin 2008), and there has been a substantial increase in female labor force participation (OECD 2012), which has reduced the differences in participation rates. Nevertheless, women still earn less than men, which is partially explained by their larger involvement in part-time work (OECD 2012). Despite their strong involvement in paid work, women are also still responsible for a disproportionately large share of household work and care, and the division of unpaid work depending on gendered norms and values in societies has changed relatively little (OECD 2012).

Health outcomes at the meso-level may be affected by the fact that in many instances micro-, meso-, and macro-level factors may counterbalance or re-inforce one another, as outlined by Oláh et al. in this volume. They give the example of women's employment, which is more likely to threaten marital stability in a country context of more traditional gender roles with particularly negative health effects for both partners. Sufficient earnings for men and high barriers of labor market entry for women would prevent women from taking up paid work, thereby losing out on the positive effects employment and increased income have on health. Having little support from the state would make employment more stressful for working parents and would reinforce the negative consequences of divorce for the economically dependent spouse.

This study tries to shed more light onto the complex relationship between household arrangements and health by concentrating on the effects of social norms. Regarding social norms, the institutionalization hypothesis originally introduced by Soons and Kalmijn (2009) proposes that in societies with a more flexible value climate, well-being is less influenced by living in a non-traditional family form. We will explore this hypothesis in the context of health, distinguishing between men 


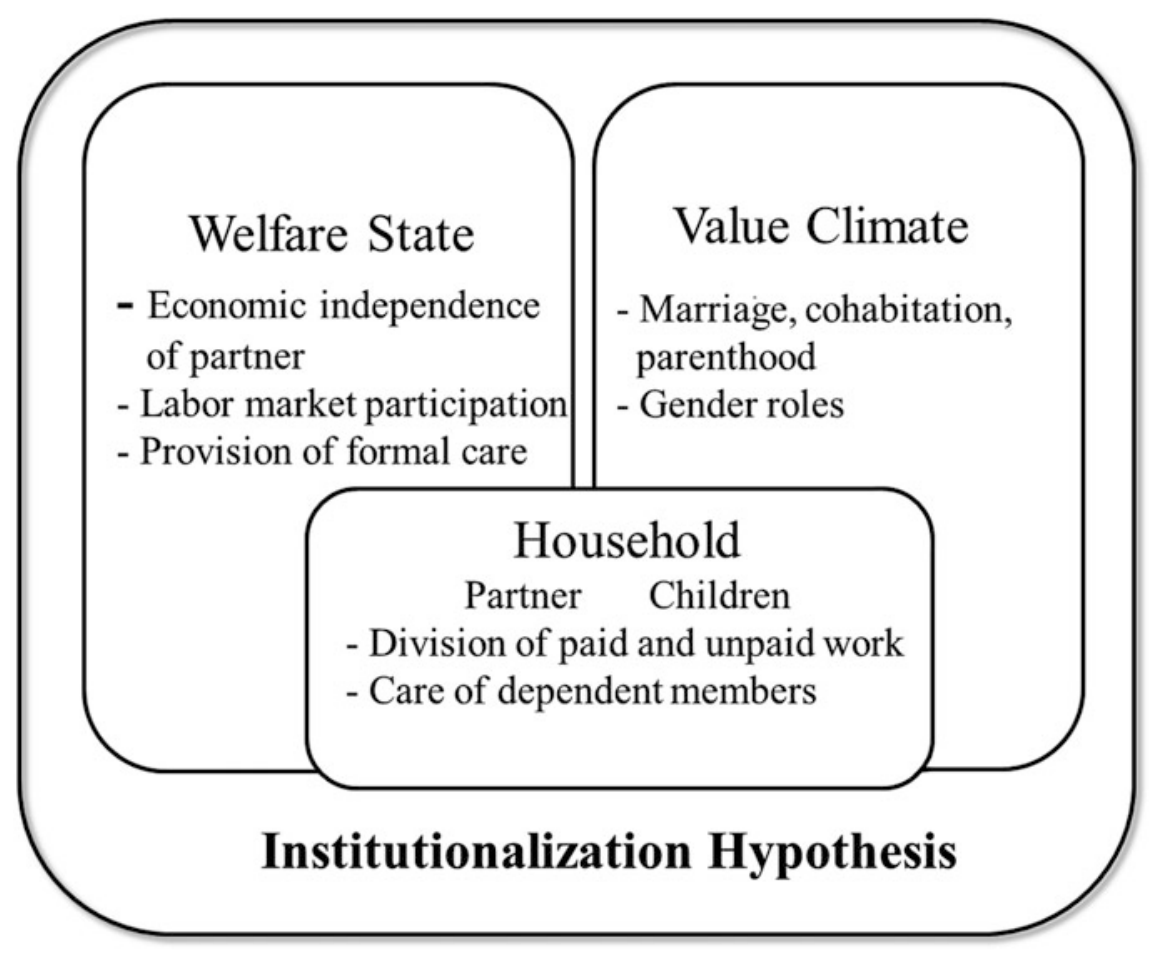

Fig. 1 Framework of the study

and women, and extend it to different family types characterized by the legal status and the presence and/or absence of a partner and of children.

This chapter is structured as follows: First, we briefly discuss health related factors at the individual level. Second, we turn to social norms and values at the macro-level, where we introduce the institutionalization hypothesis in more detail. We close this section by formulating our hypotheses in relation to health. Third, we turn to our own empirical analysis by presenting the data, the analysis strategy, and the results. Finally, we discuss to what extent the results support the institutionalization hypothesis and possible differences according to sex (Fig. 1).

\section{Household Arrangement and Health at the Individual Level}

In the European context the household arrangement among young and middle aged adults is primarily characterized by the presence or absence of a partner and/or children. There are large differences in co-residence with the parental generation, which is more widespread in Southern and Eastern Europe. We briefly discuss the health effects of partners and children below. 


\section{Partnership Effect on Health}

Living with a partner is generally associated with better health (Waite 1995; Martikainen et al. 2005), which can be explained by protective factors due to individual behavior, socio-economic conditions of both partners, and social support. In addition, the selection processes into partnership might favor the healthy candidates. A detailed discussion of these explanations can be found in the overview chapter by Hank and Steinbach in this volume and is taken up in the in-depths studies of the individual countries. Whether various types of partnership, e.g. living in a consensual union or in a marriage, differ in terms oftheir health effects depends foremost on their degree of institutionalization. While marriage is more institutionalized in most countries (Nock 1995), the value climate in (post) modern societies is more open to other forms of living arrangements than in traditional ones (Soons and Kalmijn 2009). It also depends on the spread of divorce and the propensity to enter a consensual union or marriage thereafter. Whereas living with a partner enhances each partners' health status, the termination of a union typically has a short and medium term negative effect on health, due to the disappearance of the protecting factors and the erosion of mental health associated with the process of the worsening of a couple's relationship and the subsequent separation (Waldron et al. 1997; Hughes and Waite 2009). In new partnerships, the positive health levels of the first union are often not regained (Hughes and Waite 2002; Martikainen et al. 2005). Psychological distress preceding divorce as a consequence of the worsening of the relationship between both partners appears to be more prevalent among women, whereas after-divorce depression symptoms appear to be stronger and more long-lasting among men (Williams and Umberson 2004; Rotermann 2007). Again, gender roles play an important part in this, with higher levels of gender inequalities reducing women's future capacity to cope with the consequences of divorce (Gahler 2006).

\section{Children's Effect on Health}

The second main family ties within a household are children. Their effect on health differs according to the different stages related to childbirth, infancy, and adolescence, evolving from an initial worsening immediately following the birth due to the process of adaptation to the new family status, to a posterior improvement due to the effect of the increase in both the feeling of responsibility and of social control (Barnett and Hyde 2001; Bernstein 2001). For a general overview about the relationship between the number of children and early/late childbirth, see the chapter by Hank and Steinbach as well as the in-depth study of long-term fertility consequences on health by Tomassini, Di Gessa, and Egidi (both in this volume). However, beyond either pure biological effects in the case of women or variable health stages in men (from a sense of exclusion during pregnancy to improvements once they feel more involved in tasks of caring for the baby; Bartlett 2004), the health effects of children may be strongly shaped by gender roles reflecting the macro environment in terms of the welfare state and the cultural norms, the 
economic environment, as well as individual characteristics. For instance, children show generally a positive influence on women's health, specifically on mental health (Wang 2004; Helbig et al. 2006). Nevertheless, negative effects have also been observed in diverse countries such as Sweden or Spain in relation to an overload of childcare work (Artazcoz et al. 2001; Floderus et al. 2008).

An important dimension of change in fertility behavior is the upsurge of extramarital childbearing, in connection with new partnership patterns (for a more detailed analysis of new partnership forms, see Buber and Hanappi in this volume). Another is the increase in divorce which leads to larger numbers of single parents, particular among women, who are not engaged in new partnerships. In our own empirical study, we return to the question of whether the effect of children on the health of their parents depends on the type of partnership, i.e. whether parents raising children in consensual unions experience health advantages similar to the married, and whether this effect is modulated by the societal context in different European countries. Thus, we will explore family forms differentiating between the absence and presence of a partner, as well as the legal status of the partnership.

\section{Values and Social Norms, and the Institutionalization Hypothesis}

The complexity in studying the relationship between household arrangements and health increases when different countries are compared. The changing demographic behaviors of the Second Demographic Transition (SDT),- e.g. the rise of cohabitation instead of marriage, postponement of parenthood, higher numbers of children born out of marriage, and an increase of the acceptance of divorce (van de Kaa 1994; Lesthaege 1995) - are expanding from Northern and Western Europe to Southern and Eastern Europe with different timing (Surkyn and Lesthaeghe 2004; Liefbroer and Fokkema 2008). However, the demographic behaviors among the forerunners of the SDT do not necessarily anticipate the future pattern in the other countries due to their interplay with prevailing individual values and social norms. They all affect the evolution of the diversification of family patterns within a country as well as the acceptance of these changes (Soons and Kalmijn 2009).

Individual values play an important role when trying to understand why individuals form a certain type of union in terms of cohabitation or marriage, or extramarital childbearing. It has been shown for Europe that the value orientation of individuals is associated with certain family features (Surkyn and Lesthaeghe 2004), e.g. childless cohabitants or single individuals displayed more non-conformist ${ }^{1}$ values than their married counterparts. Indeed, married individuals who had ever

\footnotetext{
${ }^{1}$ Values orientation measured by a set of different dimensions: secularization, vote to new political left, egalitarianism, unconventional civil morality and ethics, accentuation of expressive values and companionship and unconventional marital ethics.
} 
cohabited were more non-conformist than their counterparts who had never cohabited.

In addition to individual values, social norms also influence individuals' preferences for a certain family type. Basically, these norms define how appropriate a certain behavior is, as well as possible sanctions when norms are not adhered to (Liefbroer and Merz 2009; Billari and Liefbroer 2010). These norms compile shared perceptions of social tolerance to age-specific family patterns (e.g. maximum ages at which family transitions should happen or not), how often family transitions must be experienced (e.g. how many children a couple must have), and the sequence of family trajectories (e.g. having children before or after marriage) (Hofäcker and Chaloupková 2014).

Hofäcker and Chaloupková (2014) proposed that current country differences in the degree and pace of the aforementioned family changes could be explained by the different tolerance of their population to deviations from the norms. In this sense, Soons and Kalmijn (2009) introduced the hypothesis of institutionalization. The first part of the hypothesis deals with the cohabitation gap, which states that there is a disadvantage in terms of well-being for the cohabiting compared to the married. Whereas cohabitants might profit from the presence of a partner in a similar way as the married, e.g. health selection into partnership (see Hank and Steinbach in this book), a health-promoting life-style (von der Lippe and Rattay in this book), or the pooling of resources, they might also differ from the married. It has been suggested that they are less likely to be homeowners, are less committed to their relationships, have more conflicts and a worse quality of relationships (see ref. in Soons and Kalmijn 2009).

The second part of the hypothesis states that the cohabiting gap is smaller, or even non-existent, in countries where cohabiting is more frequent. Societies were placed on a continuum from traditional to (post-) modern according to the differences in their value climate, as to how they are less or more accepting of alternative living arrangements. Investigating 30 European countries, Soons and Kalmijn (2009) found strong evidence for their hypothesis.

\section{The Welfare State}

When comparing the different countries, we follow the chapter by Olah et al. in this book and distinguish five European welfare state regimes: the Dual-Earner welfare state regime with extensive policy provision facilitating a work-life balance for both women and men; the Liberal or Market Oriented regime with limited and usually means-tested state support to families and the dominance of market-based solutions regarding welfare provision; the General Family Support policy configuration type or Conservative welfare regime in which men's primacy in the labor market has not really been questioned while the range of state support to families and to women aimed at combining paid work and family responsibilities varies greatly across countries; the Familialistic or Mediterranean welfare regime with nearly no or extremely limited policy provision to families and pronounced gender role 
differentiation; and the Transition Post-Socialist regime which is also rather heterogeneous in terms of state support to families and to women in terms of combining labor market participation and family life (Esping-Andersen 1998; Hobson and Olah 2006; Neyer 2013).

\section{Aims and Hypotheses}

The aim of this study is to assess the association between the different household arrangements and self-perceived health in individuals between 30 and 59 years of age in Europe. We compare twelve countries classified into the five welfare state regimes. Comparing different countries allows us to test whether the health differentials are related to the welfare state types that are associated with different norms and values. Men and women are analyzed separately to capture gender differences according to the norms and values applying to them. We characterize household arrangements by an individual's position within the household instead of using the household as a common context for all members. The position is defined by whether the person shares a household with a partner, children, or another person outside the family nucleus. In addition, we distinguish whether partners live in a consensual union or in a marriage.

We use self-perceived health because it reflects the integral dimension of health recommended by the World Health Organization ${ }^{2}$ and has shown the capacity to capture differences in populations with a rather homogenous health profile in terms of objective health, such as is the case for young and middle aged adults. In addition, it has been shown that self-perceived health provides information about the evolution of an individual's health rather than only informing about the current status (Idler and Benyamini 1997; Gumà and Cámara 2014). However, self-perceived health levels differ widely between countries, reflecting not only differences in health but also culture-specific differences in answering health questions in surveys. Thus we do not explore country-differences between the health outcomes related to different household positions but rather the extent of the health gap between the most favorable household position and all others. A large number of studies have shown that the married with two or more children usually have the best health profile (see the chapters of Hank and Steinbach as well as Tomassini, Di Gessa, and Egidi in this volume), thus we use these as the reference group. We developed the following hypotheses extending the institutionalization hypothesis.

First, household position is more important for women's health than for men's due to the prevailing cultural norms and values.

Second, compared to the married living with children, all other household positions are disadvantaged.

Third, the health of individuals living in a consensual union is worse than of those who are married. However, based on the institutionalization hypothesis we

\footnotetext{
${ }^{2}$ Health is a state of complete physical, mental, and social well-being and not merely the absence of disease or infirmity (WHO 1946).
} 
assume that the more common this partnership form is, the lower the disadvantage. The institutionalization hypothesis might also be true for single mothers.

Fourth, financial deprivation explains some of the disadvantage of those living alone and in particular of single mothers.

\section{Data and Analysis}

\section{Data}

We used the cross-sectional microdata of the EU statistics on income and living conditions (EU-SILC) in 2012 for twelve selected countries (Spain, Italy, Poland, Hungary, Germany, Austria, France, Netherlands, Denmark, Sweden, Norway, United Kingdom). The survey units are both the household and the individual. The household level contains information on household size, composition, and basic characteristics of household members. The individual level compiles detailed information on demographic, socioeconomic, and general health issues. We restricted our study to ages 30-59. On the one hand, age 30 permits us to distinguish between those who have already started a new family and those who will likely remain in their parents' home. For the set of countries in our study the age of leaving the parental home ranges from 19.9 for Swedish women to 30.3 for Italian men (Eurostat 2016). On the other hand, the upper age boundary avoids the possible bias retirement might have on health (Demakakos et al. 2008). In 2012, the average effective age of male retirement ranged from 59.7 in France to 66.1 in Sweden, and from 59.4 in Austria to 64.3 in Norway (OECD 2016a). We also restricted our sample to native individuals of each country, in order to avoid any possible bias due to a different sociodemographic profile of migrants, as well as heterogeneity among migrants.

\section{Analysis Sample}

The sample unit of EU-SILC is the household and we have information about the kind of ties among all its members (partner without children, father, mother, child, other). This implies that it was possible to reconstruct the household position (our variable of interest) for all the interviewees in the survey. In four countries of our analysis (Sweden, Norway, Denmark, and the Netherlands) only one reference person per household answered to the entire questionnaire, which implies that the analysis sample for these countries is considerably lower than for the others.

Table 1 describes the process of individuals included in our analysis (survey sample excluding foreign-born, and sample of individuals included in our analysis) by country and sex.

The percentage of the overall response is high for all the countries with the exception of the United Kingdom, where it is lower due to the accumulation of no information in two of the variables related to socioeconomic status (educational attainment and self-defined household capacity to make ends meet). 
Table 1 Survey sample and analysis sample by country and sex

\begin{tabular}{|c|c|c|c|c|c|c|}
\hline & \multicolumn{2}{|c|}{$\begin{array}{l}\text { Survey sample } \\
\text { ages } 30-59 \\
\text { excluding } \\
\text { foreign-born }\end{array}$} & \multicolumn{2}{|c|}{$\begin{array}{l}\text { Analysis sample } \\
\text { ages } 30-59 \\
\text { excluding foreign } \\
\text { born and missing } \\
\text { information }\end{array}$} & \multicolumn{2}{|c|}{$\begin{array}{l}\text { Proportion of survey } \\
\text { sample }\end{array}$} \\
\hline & Men & Women & Men & Women & Men $(\%)$ & Women $(\%)$ \\
\hline Austria & 2590 & 2861 & 2587 & 2861 & 99.9 & 100.0 \\
\hline Germany & 5273 & 5995 & 5258 & 5980 & 99.7 & 99.7 \\
\hline Denmark $^{\mathrm{a}}$ & 1244 & 1372 & 1214 & 1339 & 97.6 & 97.6 \\
\hline Spain & 6502 & 6875 & 6353 & 6716 & 97.7 & 97.7 \\
\hline France & 5154 & 5499 & 5065 & 5419 & 98.3 & 98.5 \\
\hline Hungary & 5718 & 6693 & 5693 & 6659 & 99.6 & 99.5 \\
\hline Italy & 9272 & 9768 & 8724 & 9220 & 94.1 & 94.4 \\
\hline Netherlands ${ }^{\mathrm{a}}$ & 2551 & 2948 & 2521 & 2909 & 98.8 & 98.7 \\
\hline Norway $^{\mathrm{a}}$ & 1575 & 1388 & 1559 & 1378 & 99.0 & 99.3 \\
\hline Poland & 6783 & 7626 & 6721 & 7504 & 99.1 & 98.4 \\
\hline Sweden $^{\mathrm{a}}$ & 1333 & 1513 & 1301 & 1494 & 97.6 & 98.7 \\
\hline United Kingdom & 3894 & 4342 & 2896 & 3296 & 74.4 & 75.9 \\
\hline Total & 51,889 & 56,880 & 49,892 & 54,775 & 96.2 & 96.3 \\
\hline
\end{tabular}

${ }^{\text {a }}$ The sample is based on the reference individuals who answered all the questions

\section{Household Position}

We defined household position according to three criteria: (1) the partnership situation (living or not living with a partner); (2) living with children in the household (no children, one child, two or more children) (3) the relationship with the family nucleus ${ }^{3}$ (member of the nucleus or not). We also distinguished between cohabitation and marriage. This categorization results in the following eight household positions and two residual categories: (1) married, no children; (2) married, one child; (3) married 2+ children; (4) cohabiting, no children; (5) cohabiting, children; (6) living alone; (7) adult son/daughter living with parent(s); (8) single parent; (9) married, other; (10) not-married, other. This category of "other", married or not, includes all members of the household (relatives or not of the others) who are neither members of the nucleus nor their children (grandfather/mother, brother/ sister-in-law, etc.).

\footnotetext{
${ }^{3}$ We consider the "family nucleus" as the adult or couple of adults who can be considered as the reference of the household (main person or persons in charge of paid and unpaid work) and who are in the age range of our study (30-59). In the case of multigenerational households, we prioritized the youngest nucleus under the assumption that they are more likely to live with school age children, who need more attention from parents.
} 


\section{Health}

We used the question about self-perceived health "What is your state of health in general?" and combined the two answers very good and good into one category which we labelled "good health," and the three answers fair, poor, and very poor into another category labelled "poor health." In a sensitivity analysis we also explored whether assigning the middle category of fair to good health would change our results, which was not the case.

\section{Covariates}

We controlled for age by using the three age groups 30-39, 40-49, and 50-59. We used two indicators to account for individual socio-economic status: First, the highest educational attainment (defined by $\mathrm{ISCED}^{4}$ ). The original seven educational levels were aggregated into three categories: lower secondary education or lower (pre-primary education, primary education, and lower secondary education); upper secondary education (upper secondary education and post-secondary non tertiary education); and tertiary education (first stage of tertiary education (not leading directly to an advanced research qualification) and second stage of tertiary education (leading to an advanced research qualification)). Second, we used the self-defined current economic status of the individual (basic labor information on current activity status and on current job). The answers were categorized into: employed (employee working full or part-time), self-employed working full or part-time (including family workers); unemployed; fulfilling domestic tasks and care responsibilities (mainly a female situation in almost all the analyzed countries); and other economically inactive situations (in compulsory military community or service; pupil, student, further training, unpaid work experience; in retirement or in early retirement or has given up business and permanently disabled or/and unfit to work). Although this last group is the aggregation of four possible answers, the majority of individuals belong to the last two previously mentioned groups, due to the age range of analysis.

To test whether financial deprivation may account for some of the differences in health by household position, we used the information on self-defined ability to make ends meet in the household (thinking of your household's total income, is your household able to make ends meet, namely, to pay for its usual necessary expenses?). This question was posed at the household level and we categorized the answers into four categories: with difficulty (with difficulty or great difficulty); with some difficulty; fairly easily; and easily (easily and very easily). Table 2 provides information on all individual level variables.

\footnotetext{
${ }^{4}$ International Standard Classification of Education.
} 
Table 2 Characteristics of the analysis sample

\begin{tabular}{|c|c|c|c|c|}
\hline \multirow[b]{2}{*}{ Age } & \multicolumn{2}{|l|}{ Men } & \multicolumn{2}{|l|}{ Women } \\
\hline & Mean & SD & Mean & SD \\
\hline & 45.4 & 8.38 & 45.45 & 8.41 \\
\hline & $\mathbf{N}$ & $\%$ & $\mathbf{N}$ & $\%$ \\
\hline \multicolumn{5}{|l|}{ Subjective health } \\
\hline Good health & 37,970 & 76.1 & 40,037 & 73.1 \\
\hline Poor health & 11,922 & 23.9 & 14,738 & 26.9 \\
\hline \multicolumn{5}{|l|}{ Education } \\
\hline Pre-primary and primary & 2587 & 5.2 & 3093 & 5.6 \\
\hline Secondary & 31,925 & 64.0 & 32,818 & 59.9 \\
\hline Post-secondary/tertiary & 15,380 & 30.8 & 18,864 & 34.4 \\
\hline \multicolumn{5}{|l|}{ Self-defined current economic status } \\
\hline Employee & 34,076 & 68.3 & 33,710 & 61.5 \\
\hline Self-employed & 7316 & 14.7 & 4057 & 7.4 \\
\hline Unemployed & 4266 & 8.6 & 4586 & 8.4 \\
\hline Fulfilling domestic tasks and care responsibilities & 201 & 0.4 & 7025 & 12.8 \\
\hline Other inactive person & 4033 & 8.1 & 5397 & 9.9 \\
\hline \multicolumn{5}{|l|}{ Self-defined ability to make ends meet } \\
\hline With difficulty & 12,933 & 25.9 & 15,177 & 27.7 \\
\hline With some difficulty & 13,949 & 28.0 & 15,514 & 28.3 \\
\hline Fairly easily & 12,770 & 25.6 & 13,700 & 25.0 \\
\hline Easily & 10,240 & 20.5 & 10,384 & 19.0 \\
\hline Total & 49,892 & 100.0 & 54,775 & 100.0 \\
\hline
\end{tabular}

\section{Macro Variables}

To test the institutionalization hypothesis, we used the country-specific proportion of a certain household position as noted in Table 3. To make the results comparable in our multivariate analyses we standardized the proportions over all household positions to mean zero and variance one. In a sensitivity analysis we also standardized the proportions within each household position, which did not change our results.

\section{Analysis Strategy}

The analysis strategy comprised three steps. The first step is the descriptive analysis of the household position patterns of the countries. We discuss the results on the level of the welfare state to provide the general picture, even if there are still country differences within the welfare state regions. The second step comprises the multivariate analyses, using logistic regression models of poor health, which explore the health advantage/disadvantage of a specific household position in comparison to the 


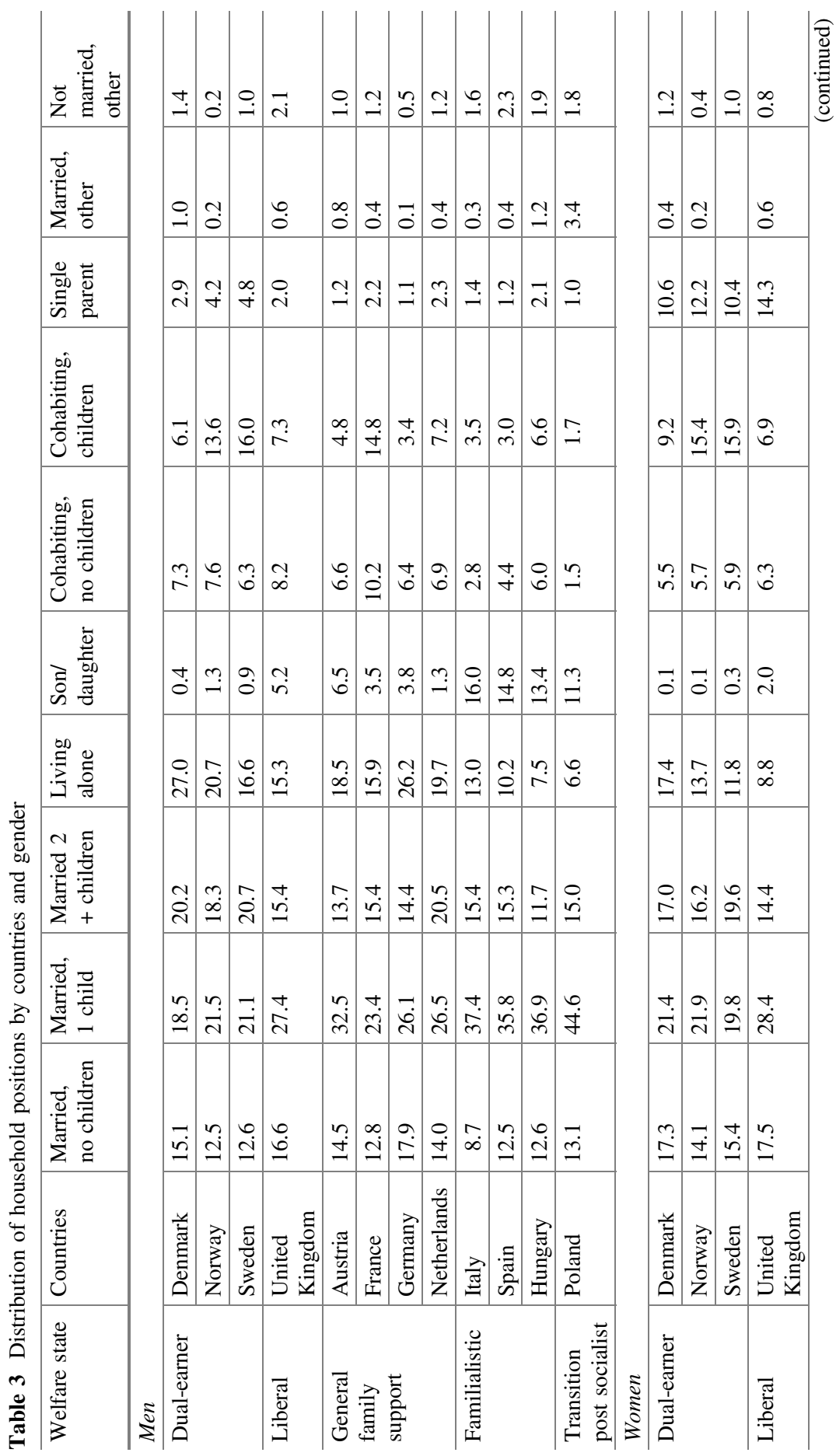




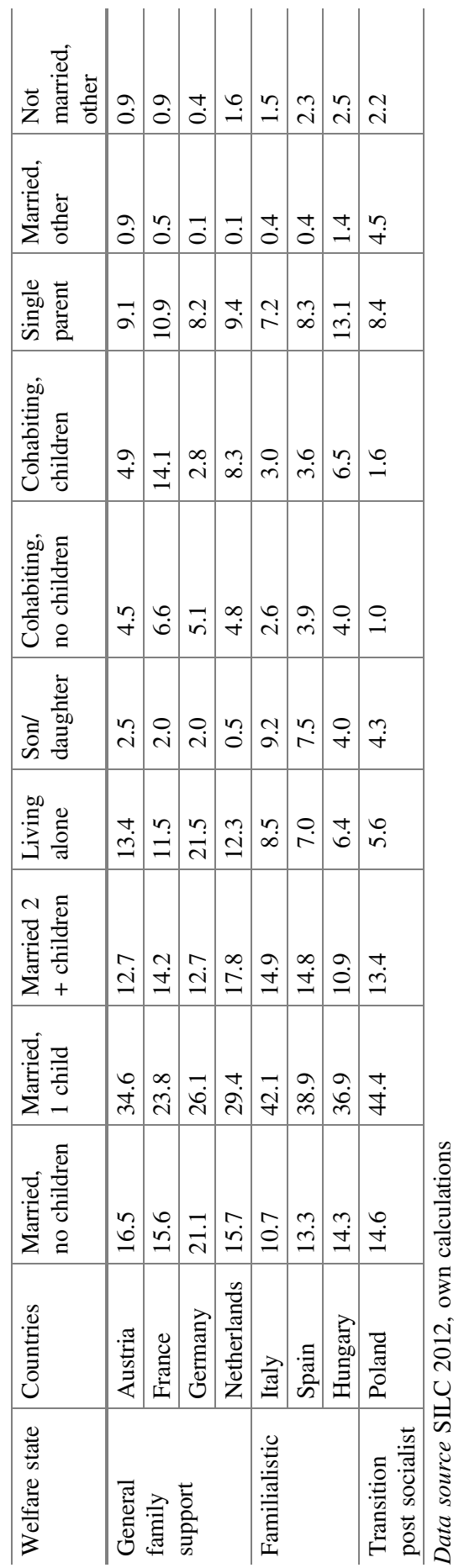


position "married with children" separate for the two sexes and by individual country. All models were controlled for socio-economic characteristics and age. By entering the variable about "financial difficulties in making ends meet" we explored whether economic deprivation may be a mediator that could explain health differences between household positions. The third step consisted of a set of statistical meta-analyses which correlated the frequency of a certain household position in a country with the estimated odds ratio of poor health in comparison to the married with children. Using a relative measure such as the odds ratio rather than the level of poor health solves the problem of country-specific cultural practices and norms in answering health questions. Here we observe the relative difference in health to the married with children, which is independent from the level of health in a given country. The analyses in steps two and three use country information rather than welfare-state-specific information to take full advantage of the heterogeneity between the countries. Descriptive analyses and the multivariate regression models are performed in SPSS; the meta-regression is estimated in Stata using the command "metareg". In the meta-regression the macro variables (= frequency of the household position) is regressed on the parameter estimates of the household positions stemming from the logistic regression models estimated in step two (models without controlling for financial difficulties). The parameter estimates are weighted by their precision, i.e. the inverse of their standard deviation. Results are presented in the form of scatter plots, where the size of a data point represents its precision. The values of parameter Beta are interpreted in terms of standard deviations: e.g. a Beta of 0.05 indicates that a change of one standard deviation in the macro variable increases the parameter estimate of the logistic regression by 0.05 (say from 0.50 to 0.55 , which is an increase in the odds ratio from 1.65 to 1.73 ). In a sensitivity analysis we ran the meta-regression using parameter estimates from the logistic regressions controlled for the effect of financial deprivation. This generally resulted in an attenuation of the correlations (results not shown).

\section{Results}

\section{Descriptives}

\section{Household positions involving married partners}

The most frequent household positions are those involving married partners (Table 3). In all welfare state regimes, the most frequent position among both women and men is "married, 1 child", which is particularly large in the Familialistic and Transition Post Socialist (TPS) countries and lowest in the Nordic Dual-Earner countries. Also for both sexes the position "married, 2+ children" comes second, and tends to be less frequent in the Familialistic and TPS countries. 


\section{Living alone and living as son/daughter with parents}

For the household positions involving non-married individuals there are clear differences between the welfare state regimes. Overall, men live alone more frequently and they tend to outnumber married men without children and those with more children in the household. Again, the Familialistic and TPS countries are an exception, with low proportions living alone but a considerable number of adults of both sexes living as sons and daughters in the households of their parents. We can observe a group of countries where men living alone are more frequent than their counterparts living in their parents' home (France, Germany, and the United Kingdom); and countries where men living with their parents show higher percentages than those living alone (Spain, Italy, Poland, and Hungary). As this is cross-sectional data, we do not know whether the latter have always been living with their parents or whether they moved back.

\section{Cohabiting and single parents}

"Cohabiting, no children" is slightly more common among men than women, "cohabiting, children" appears to be equal among the two sexes. While cohabiting is rather uncommon in the Familialistic and TPS countries, is it quite frequent in the other welfare state regimes, particularly in the Nordic Dual Earner countries but also in France. In all countries, single parent mothers largely outnumber single parent fathers. With the exception of the Nordic Dual-Earner countries and France, they are more frequent than cohabiting mothers; in the Familialistic and TPS countries they are more frequent than women living alone or living as adult daughters with parents. We may hypothesize that after a partnership breaks up women tend to continue living alone with their children whereas men, depending on the welfare state regime, either live alone, go back to their parental home, or enter a cohabitation.

\section{Multivariate Analysis}

\section{Health patterns by household position}

Starting with the most common household positions, those which involve married partners, we found that married individuals with two or more children are usually the healthiest (Table 4). This holds true for all welfare state regimes and for both sexes, however, with few exceptions the effects were stronger among women. Among married women the health difference according to the number of children living in the household lacked statistical significance in the Nordic Dual-Earner countries (with the exception of the United Kingdom), was particularly pronounced in the Familialistic and TPS countries, but also present in the General Family Support regime. Among married men, differences were statistically significant only in the Familialistic and TPS countries. 


\begin{tabular}{|c|c|c|c|c|c|c|c|c|c|c|c|c|c|c|c|c|c|c|}
\hline & & $\frac{.00}{n^{2}}$ & 旁 & \begin{tabular}{|l|} 
粹 \\
\end{tabular} & \begin{tabular}{|l|l|} 
\\
\end{tabular} & 菨 & $*$ & 歖 & & 㳯 & & * & & * & * & & & \\
\hline & 触 & б & & $\mid \overrightarrow{\vec{i}_{i}}$ & 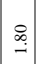 & & $\stackrel{9}{\leftrightarrows}$ & 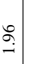 & $\stackrel{8}{\circ}$ & $\stackrel{f}{=}$ & $\stackrel{8}{-}$ & 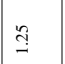 & $\stackrel{\leftrightarrow}{\leftarrow}$ & f & 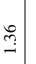 & $\cong$ & ભొ & 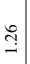 \\
\hline & 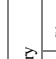 & $\frac{D p}{20}$ & 旁 & \begin{tabular}{|l|} 
\\
\\
\end{tabular} & \begin{tabular}{|l|l} 
\\
\\
\end{tabular} & $\frac{.}{\frac{*}{*}}$ & & 旁 & & 善 & & * & & * & $\approx$ & & & \\
\hline & 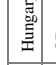 & б. & & 空 & $\stackrel{-}{-}$ & & $\stackrel{\infty}{\stackrel{\infty}{-}}$ & $\stackrel{\overbrace{}}{=}$ & m. & בุ & $\underset{-}{8}$ & $\stackrel{q}{q}$ & $\stackrel{n}{I}$ & : & P & 热 & $\fallingdotseq$ & $\stackrel{\bullet}{-}$ \\
\hline & & $\frac{20}{n}$ & 橲 & \begin{tabular}{|l|} 
\\
\end{tabular} & \begin{tabular}{|l|} 
\\
\end{tabular} & 旁 & 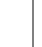 & 善 & 美 & 粹 & &. & & $\approx$ & * & $=$ & & \\
\hline & 高 & 。 & & $\stackrel{\stackrel{2}{i}}{\mathrm{i}}$ & \begin{tabular}{|c|} 
\\
- \\
-
\end{tabular} & & $\begin{array}{c}\stackrel{+}{a} \\
\stackrel{5}{\circ}\end{array}$ & 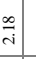 & $\vec{a}$ & $\begin{array}{l}b \\
\tilde{r} \\
\end{array}$ & $\stackrel{8}{-}$ & 节 & 声 & : & $\stackrel{0}{\leftrightarrows}$ & $\stackrel{n}{n}$ & $\stackrel{n}{\leftrightarrows}$ & $\stackrel{\circ}{\stackrel{2}{*}}$ \\
\hline & & $\frac{\infty}{n \pi}$ & $\frac{*}{*}$ & 喜 & 辡 & 幕 & & 善 & * & 丵 & & * & $=$ & $*$ &. & & & \\
\hline & 蚉 & 。 & & $\underset{\gamma}{2}$ & $\underset{i}{ \pm}$ & & $\stackrel{0}{0}$ & $\stackrel{8}{i}$ & $\stackrel{n}{n}$ & $\stackrel{\cong}{\Xi}$ & $\stackrel{8}{-1}$ & $\underset{t}{ \pm}$ & తి & ติ) & $\stackrel{\infty}{\stackrel{\infty}{\rightarrow}}$ & $\exists$ & $\exists$ & $\stackrel{5}{-}$ \\
\hline & & & 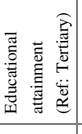 & 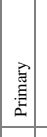 & 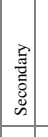 & 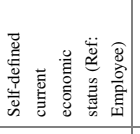 & 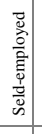 & | & 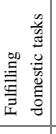 & 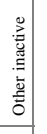 & 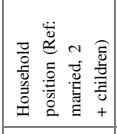 & 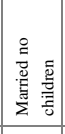 & 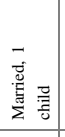 & 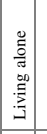 & 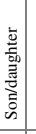 & 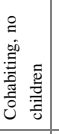 & 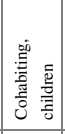 & 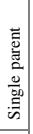 \\
\hline & 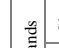 & $\frac{20}{50}$ & 草 & \begin{tabular}{|l|l} 
\\
\\
\end{tabular} & \begin{tabular}{|l|} 
\\
\\
\end{tabular} & 章 & & 榇 & 1 & 丵 & & $=$ & $*$ & $\begin{array}{l} \\
\\
*\end{array}$ & & & & \\
\hline & 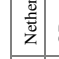 & \% & & $\begin{array}{c}q \\
f \\
f\end{array}$ & $\mid \begin{array}{c}\infty \\
- \\
-\end{array}$ & & 5 & $\underset{i}{\vec{i}}$ & 1 & $\begin{array}{l}\infty \\
\stackrel{\infty}{\vartheta} \\
\stackrel{2}{2}\end{array}$ & $\stackrel{8}{-}$ & $\stackrel{n}{=}$ & $\stackrel{\infty}{-}$ & 2 & & 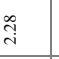 & $\stackrel{\leftrightarrow}{\rightarrow}$ & $\stackrel{8}{-}$ \\
\hline & & in & 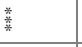 & \begin{tabular}{|l|} 
\\
\\
$*$
\end{tabular} & \begin{tabular}{|l|l|} 
\\
\end{tabular} & 並 & & 菨 & * & 善 & & & & $\begin{array}{l} \\
\\
\end{array}$ & & & & \\
\hline & 总 & \% & & $\begin{array}{c}\mathcal{g} \\
f \\
\end{array}$ & \begin{tabular}{l}
$\infty$ \\
\hdashline \\
-
\end{tabular} & & $\hat{a}$ & | & $\stackrel{\vec{i}}{\vec{i}}$ & 声 & $\stackrel{8}{-}$ & 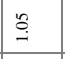 & $\stackrel{8}{:}$ & : & $\stackrel{9}{=}$ & 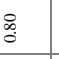 & $\stackrel{\overbrace{}}{-}$ & $\stackrel{\leftrightarrow}{\rightarrow}$ \\
\hline & & 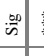 & 動 & \begin{tabular}{|l|}
$*$ \\
\end{tabular} & \begin{tabular}{|l|l} 
& 丵 \\
\end{tabular} & 旁 & & 薏 & & 丵 & & & & $\approx$ &. & & & \\
\hline & 喠 & б. & & $\mid$\begin{tabular}{l}
$\infty$ \\
\hdashline \\
\hdashline
\end{tabular} & $\stackrel{\sqrt[n]{-}}{-1}$ & & $\vec{\Xi}$ & 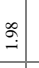 & : & cे & $\stackrel{8}{-}$ & I & $\stackrel{n}{g}$ & के & 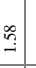 & $\stackrel{9}{\rightrightarrows}$ & $\fallingdotseq$ & S. \\
\hline & 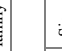 & $\frac{.00}{v^{2}}$ & 辜 & 絭 & \begin{tabular}{l|l} 
\\
\end{tabular} & 嘉 & & 菨 & & $\frac{.}{*}$ & & & $*$ & * &. & & & \\
\hline & $\begin{array}{c}3 \\
\vdots\end{array}$ & \% & & 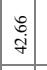 & $\mid$\begin{tabular}{l|}
$f$ \\
in \\
\end{tabular} & & ฐิ & fo & $\exists$ & 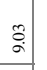 & $\stackrel{8}{-1}$ & $\cong$ & $\stackrel{\infty}{3}$ & 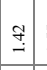 & 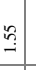 & 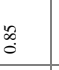 & $\stackrel{\leftrightarrow}{0}$ & 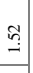 \\
\hline & & & 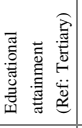 & 竞 & 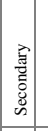 & 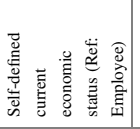 & 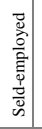 & | & 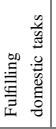 & 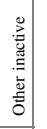 & 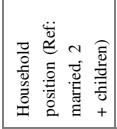 & 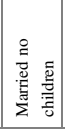 & 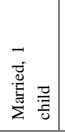 & 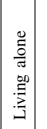 & 竧 & 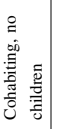 & 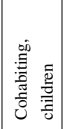 & 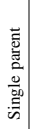 \\
\hline & & $\frac{.00}{20}$ & 旁 & & \begin{tabular}{l|l} 
\\
\\
\end{tabular} & 塨 & & 丵 & & $\frac{.}{*}$ & & & & 丵 & & & & \\
\hline & 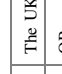 & б. & & & \begin{tabular}{|c|} 
\\
\\
\end{tabular} & & $\stackrel{9}{=}$ & ले & త] & $\stackrel{3}{3}$ & $\stackrel{8}{-}$ & 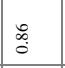 & S. & 总 & 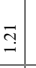 & کू & $\Xi$ & $\stackrel{2}{=}$ \\
\hline & & $\frac{20}{25}$ & $\approx$ &. & $=$ & 旁 & $\begin{array}{l} \\
* \\
\end{array}$ & & & 善 & & & & $\approx$ & I & & & \\
\hline & 童 & \% & & $\stackrel{\grave{2}}{\grave{c}}$ & 声 & & & $\stackrel{\Omega}{\rightarrow}$ & $\bar{F}$ & $\begin{array}{l}n \\
0 \\
0\end{array}$ & 8 & 恋 & $\cong$ & $\stackrel{\infty}{\rightarrow}$ & & $\exists$ & $\begin{array}{c}\infty \\
\stackrel{\infty}{\circ}\end{array}$ & $\begin{array}{c}\infty \\
\infty \\
\infty \\
0 \\
0\end{array}$ \\
\hline & & in & * & & $*$ & 醉 & $*$ & 蕃 & & 蒂 & & & & * & & & & $\therefore$ \\
\hline & 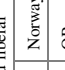 & $\approx$ & & \begin{tabular}{|c|}
$\tilde{F}$ \\
\end{tabular} & \begin{tabular}{|c|c} 
\\
\hdashline
\end{tabular} & & $\begin{array}{l}\underset{\mathrm{i}}{\mathrm{S}} \\
\end{array}$ & ले & 8 & $\bar{\sigma}$ & $\underset{-}{8}$ & $\stackrel{\infty}{\rightarrow}$ & $\cong$ & \begin{tabular}{|l|} 
\\
\\
\end{tabular} & & 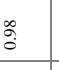 & $\stackrel{\Xi}{I}$ & $\stackrel{\mathscr{\infty}}{-}$ \\
\hline & 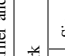 & $\frac{.00}{n 2}$ & * & 1 & * & 意 & & * & 1 & 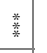 & & & * & \begin{tabular}{|l|}
\multirow{3}{*}{} \\
\end{tabular} & & & 旁 & \\
\hline & & of & & 1 & $\bar{n}$ & & $\begin{array}{l}0 \\
0 \\
0\end{array}$ & 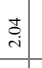 & 1 & $\stackrel{?}{=}$ & $\underset{-1}{8}$ & $\stackrel{\mathscr{\infty}}{-}$ & $\stackrel{\infty}{\mathrm{s}}$ & $\begin{array}{l}8 \\
\end{array}$ & ते & $\stackrel{\infty}{\rightarrow}$ & ส & है \\
\hline & & & 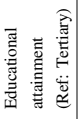 & $\mid$ & 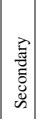 & 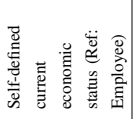 & 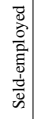 & & 童童 & 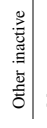 & 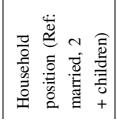 & 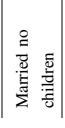 & 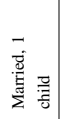 & 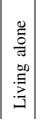 & 产| & | & 望 & \\
\hline
\end{tabular}




\begin{tabular}{|c|c|c|c|c|c|c|c|c|c|c|c|c|c|c|c|c|c|c|c|c|}
\hline & 学 & & & \begin{tabular}{|l|} 
咅 \\
\end{tabular} & & & 圅 & 亲 & 菨 & 粪 & & $*$ & 絭 & 章 & 薏 & * &. & 蕃 & & 菜 \\
\hline & 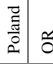 & $5 \stackrel{t}{:}$ & $\stackrel{9}{\leftrightarrows}$ & $\begin{array}{l}9 \\
0 \\
\end{array}$ & 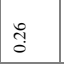 & 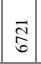 & $\stackrel{8}{n}$ & : & $\stackrel{\infty}{\dddot{\infty}}$ & 定 & $\stackrel{-}{-}$ & $\stackrel{0}{0}$ & 志 & $\stackrel{\infty}{\leftrightharpoons}$ & : & f & I & | & $\stackrel{7}{\exists}$ & $\stackrel{9}{-1}$ \\
\hline & 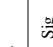 & & & \begin{tabular}{|l|} 
\\
\multirow{*}{*}{$*$}
\end{tabular} & & & & 莘 & * & 莑 & & 菜 & 蕃 & 萻 & 蕃 & 菜 & * & 絭 & * & 菜 \\
\hline $\mid$ & 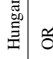 & $5 \stackrel{్}{5}$ & $\stackrel{\infty}{0}$ & $\mid \stackrel{0}{\circ}$ & लू & 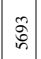 & g. & $\overline{\vec{i}}$ & తి & $\underset{+}{F}$ & $\stackrel{8}{-}$ & $\stackrel{\infty}{\stackrel{\infty}{-}}$ & in & $\mid \begin{array}{c}\underset{\mathrm{i}}{\mathrm{i}} \\
\mid\end{array}$ & ڤ̆ & $\stackrel{\circ}{\leftrightarrows}$ & : & 帒 & ֶี & ڤั \\
\hline$\frac{2}{8}$ & $\therefore$ & 臂 & & \begin{tabular}{|l|} 
\\
丵
\end{tabular} & & & & 尊 & 菨 & 丵 & & 蕫 & 粰 & 丵 & 䧿 & : & * & 嬉 & 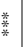 & 嶪 \\
\hline 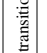 & 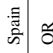 & i & Ғ & $\mid \begin{array}{l}8 \\
:\end{array}$ & ḋ & $\begin{array}{l}0 \\
0 \\
0\end{array}$ & $\cong$ & $\underset{\underset{\alpha}{+}}{+\underset{+}{+}}$ & के & 总 & $\underset{-}{8}$ & gे & $\stackrel{\approx}{2}$ & 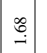 & 总 & $\stackrel{\leftrightarrow}{g}$ & î & . & $\stackrel{ \pm}{ \pm}$ & สี \\
\hline 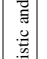 & is & 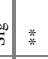 & \begin{tabular}{|l|} 
萻 \\
\end{tabular} & \begin{tabular}{|l|} 
觪 \\
\end{tabular} & & & 菜 & 莣 & 善 & 粋 & & 善 & 粼 & \begin{tabular}{|l|l|} 
\\
\end{tabular} & 蕃 & $=$ & * & 蓄 & 蒡 & 嗞 \\
\hline ] & $\frac{\vec{z}}{\underline{\underline{a}}}$ \% & 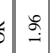 & : & $\mid \begin{array}{ll} \\
\stackrel{0}{0}\end{array}$ & $\stackrel{t}{0}$ & 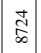 & $E$ & $\vec{i}$ & 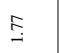 & $\overrightarrow{\vec{s}}$ & $\underset{-}{\stackrel{-}{-}}$ & $\stackrel{-}{t}$ & $\stackrel{n}{\stackrel{2}{2}}$ & $\mid \frac{\infty}{\mathrm{s}}$ & 它 & 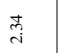 & : & ส & . & $\stackrel{8}{9}$ \\
\hline & & 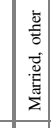 & 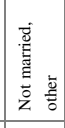 & 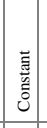 & 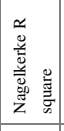 & z & 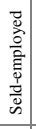 & 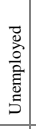 & 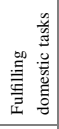 & 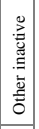 & 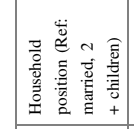 & 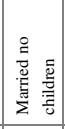 & 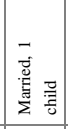 & 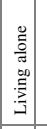 & 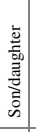 & 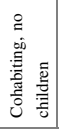 & 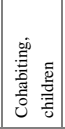 & 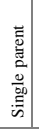 & 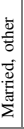 & 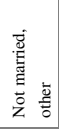 \\
\hline & 至 & 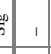 & & \begin{tabular}{|l|} 
\\
\end{tabular} & & & & 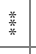 & * & 菜 & &. & . & \begin{tabular}{|l|l|l}
\multirow{3}{*}{$*$} \\
\end{tabular} & I & & & 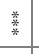 & & \\
\hline & $\begin{array}{l}\frac{\tilde{a}}{\tilde{m}} \\
\bar{z}\end{array}$ & $\frac{1}{6}$ & : & $\mid \begin{array}{c}\mid \\
\vdots \\
0\end{array}$ & สุ & $\mid \vec{a}$ & S: & ळ్ & $\underset{i}{g}$ & $\stackrel{2}{\circ}$ & $\stackrel{8}{-}$ & $\exists$ & J & 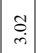 & 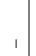 & $\overrightarrow{\mathrm{s}}$ & 导 & . & & 紫 \\
\hline & 然 & & & \begin{tabular}{|l|} 
\\
\end{tabular} & & & & 菨 &. & \begin{tabular}{|l|}
$*$ \\
$*$ \\
$*$
\end{tabular} & & * & & \begin{tabular}{|l|}
$*$ \\
$*$
\end{tabular} & * & & & * & & \\
\hline & 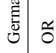 & 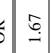 & : & $\mid \begin{array}{c}\infty \\
:\end{array}$ & ন্ড & 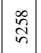 & $\stackrel{8}{\exists}$ & $\underset{\substack{\infty \\
\multirow{r}{*}{}}}{ }$ & $\stackrel{\infty}{\dddot{I}}$ & 守. & $\stackrel{8}{-}$ & g & $\exists$ & 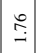 & $\stackrel{\overbrace{}}{-}$ & ๕્વ & $\overrightarrow{3}$ & 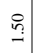 & :ี & $\stackrel{\infty}{\dddot{7}}$ \\
\hline & and & & * & \begin{tabular}{|l|} 
\\
丵
\end{tabular} & & & & * & & 菩 & & * & * & 薏 & & & & 粘 & 草 & * \\
\hline : & 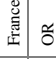 & 5 & $\stackrel{\not \underset{\infty}{-}}{-}$ & $\because$ & gे & 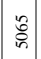 & 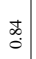 & $\stackrel{n}{?}$ & 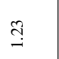 & $\mid \begin{array}{c}\tilde{y} \\
\tilde{i}\end{array}$ & $\underset{-}{\stackrel{-}{-}}$ & $\stackrel{2}{2}$ & F & $\stackrel{\infty}{\stackrel{\infty}{:}}$ & $\underset{\Xi}{\unlhd}$ & $\overrightarrow{\underline{I}}$ & gे & $\underset{\sim}{\stackrel{\infty}{-}}$ & 离 & $\vec{m}$ \\
\hline 顏 & in & $\begin{array}{ll}20 \\
2\end{array}$ & & \begin{tabular}{|l|} 
\\
\end{tabular} & & & & 萻 & & 羓 & & 菨 & * & 萻 & & & & 喜 & $=$ & \\
\hline 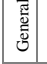 & 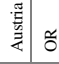 & 5 & $\bar{\Xi}$ & \begin{tabular}{|c|c|} 
\\
$\vdots$ \\
\end{tabular} & â & 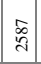 & $\stackrel{0}{\circ}$ & $\stackrel{\infty}{\circ}$ & $\stackrel{m}{3}$ & 年 & $\stackrel{-}{-}$ & $\frac{\stackrel{े}{\mathrm{i}}}{2}$ & $\stackrel{2}{9}$ & $\mid$\begin{tabular}{l|} 
\\
\multirow{2}{*}{} \\
$\mathrm{i}$
\end{tabular} & g) & $\stackrel{8}{.}$ & $\stackrel{\infty}{\rightarrow}$ & $\mid \begin{array}{c}\hat{i} \\
\end{array}$ & fof & $\stackrel{\infty}{i}$ \\
\hline & & 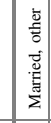 & 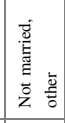 & 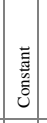 & 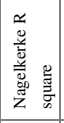 & z & 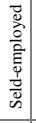 & 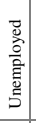 & 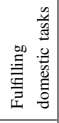 & 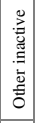 & 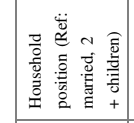 & 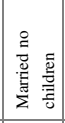 & 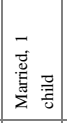 & 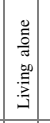 & 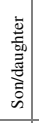 & 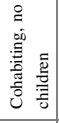 & 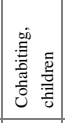 & 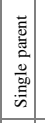 & 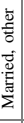 & 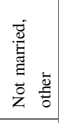 \\
\hline & $\frac{60}{20}$ & & * & \begin{tabular}{|l|} 
辡 \\
\end{tabular} & & & & 蒡 & $\frac{*}{*}$ & \begin{tabular}{|l|} 
\\
$*$ \\
$*$
\end{tabular} & & $*$ & * & 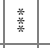 & 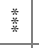 & $*$ & 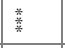 & $\begin{array}{l}\text { 意 } \\
\end{array}$ & & $=$ \\
\hline & 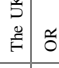 & 5 & $\vec{i}$ & \begin{tabular}{|c|c|} 
\\
8 \\
8
\end{tabular} & $\stackrel{\infty}{a}$ & 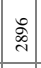 & $\begin{array}{c}\text { a. } \\
\text { of }\end{array}$ & 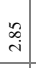 & $\frac{\text { i }}{\circ}$ & $\bar{\sigma}$ & 8 & 表 & $\stackrel{\infty}{\leftrightarrows}$ & 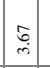 & ले & $\stackrel{\infty}{-}$ & స్ & $\mid \begin{array}{l}\infty \\
\vdots \\
\text { in }\end{array}$ & $\overrightarrow{0}$ & बे \\
\hline & $\frac{.00}{50}$ & 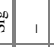 & 1 & \begin{tabular}{|l|} 
\\
蔁
\end{tabular} & & & 羓 & 蒡 & & 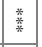 & & & & & I & & & $\begin{array}{l}\text { 粹 } \\
\end{array}$ & & I \\
\hline & 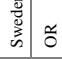 & 5 & 1 & $\begin{array}{l}5 \\
0 \\
\end{array}$ & $g$ & $\vec{D}$ & & $\vec{m}$ & $\stackrel{\mathscr{\infty}}{0}$ & 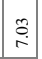 & $\stackrel{8}{-}$ & \% & ন্ডী & g & & 志 & 年 & $\stackrel{\circ}{m}$ & & I \\
\hline & $\frac{.00}{i 2}$ & $\frac{20}{2}$ & 1 & 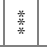 & & & & * &. & $\begin{array}{l}* \\
* \\
*\end{array}$ & & & & $*$ & I & & & 旁 & & 1 \\
\hline 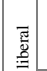 & 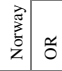 & 5 & 1 & $\begin{array}{l}5 \\
0 \\
\end{array}$ & $\stackrel{9}{0}$ & 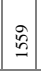 & $\Xi$ & $\stackrel{\vec{d}}{\vec{j}}$ & $\underset{\mathrm{i}}{\stackrel{8}{0}}$ & $\mid \begin{array}{l}0 \\
\mathrm{~d}\end{array}$ & $\underset{-}{8}$ & I & 导 & 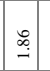 & & $\vec{I}$ & gे & 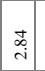 & & 1 \\
\hline 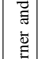 & $\therefore$ & & & \begin{tabular}{|l|} 
\\
\end{tabular} & & & & 蒡 & 1 & \begin{tabular}{|l|} 
\\
\end{tabular} & & & & * & & & & & & \\
\hline 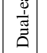 & 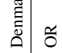 & 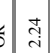 & 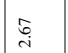 & $\stackrel{5}{0}$ & శ్ & $\stackrel{\Xi}{\Omega}$ & $\begin{array}{l}0 \\
\vdots \\
:\end{array}$ & $\stackrel{\circ}{\circ}$ & , & {$\left[\begin{array}{l}0 \\
0 \\
\infty\end{array}\right]$} & $\underset{-1}{8}$ & $\stackrel{\circ}{\leftrightarrows}$ & g. & $\vec{m}$ & & $\stackrel{9}{\exists}$ & 3 & $\vec{I}$ & & 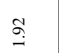 \\
\hline & & 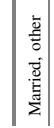 & 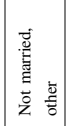 & $\mid$ & 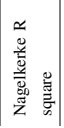 & & 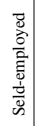 & & 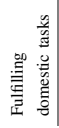 & & 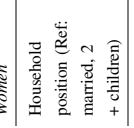 & 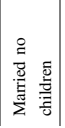 & 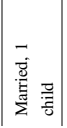 & 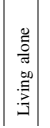 & 总 & 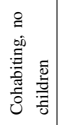 & 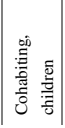 & 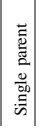 & & 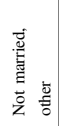 \\
\hline
\end{tabular}




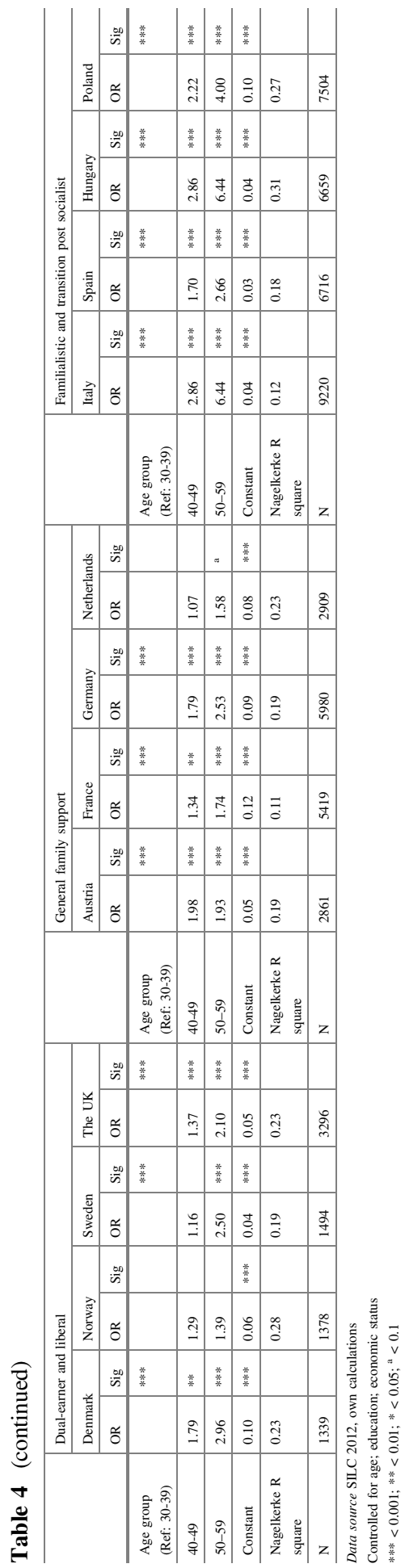


Compared to married individuals with children, those living alone or with their parents are generally disadvantaged in their health, independent of the welfare state regime. Effect sizes are particularly large and highly significant in the Familialistic and TPS countries, and women appear to be even more affected than men. Another highly disadvantaged group is single mothers - independent of the welfare state regime they suffer exceptional worse health than their married counterparts. For men the effect is neither consistent nor significant, probably due to small sample sizes.

In all welfare state regimes, cohabitation does not seem to involve any significant negative health effects for men. In some countries odds ratios are not even elevated. However, in the Familialistic and TPS countries cohabiting women experience a significant health disadvantage.

While the country specific results within welfare state regimes are homogenous, there are two countries that stand out. Denmark, in the group of Dual-Earner countries, shows large negative health effects for men who live with a partner and only one child (as compared to married with more children). Men in the Netherlands, a country of the general family support regime, have significantly worse health if they are married but live in households with no or only one child.

\section{Mediator Analysis of Financial Deprivation}

The health effects described above are controlled for socio-economic characteristics, however, financial deprivation might still play an important role in explaining the differences observed. Introducing the variable "difficulties in making ends meet" in the models has huge effects on the odds ratios (Table 5). A positive sign indicates that individuals occupying a certain household position are financially better off than the married with more children, which (partly) attenuates their health disadvantage. A negative sign indicates that the health disadvantage is partly due to financial deprivation. Among men positive signs tend to dominate, which indicates that the health disadvantage compared to the married with children is larger if one accounts for financial deprivation, i.e. the married with children seem to be worse off in financial terms, which affects their health. Among women, financial difficulties appear to be partly responsible for the health disadvantage of single mothers and of women living alone; as in the case of men, married women with no or one child seem to fare financially better than the married with more children, which slightly attenuates their health disadvantage.

\section{Testing the Institutionalization Hypothesis}

The institutionalization hypothesis suggests that the more frequent a certain household position is, the less it is stigmatized, thus the health disadvantage compared to the married living with two children should decrease. This implies that we are looking for a negative correlation between the odds ratio of poor health and 
Table 5 Mediator effect of financial deprivation on the odds ratios of poor health by household position

\begin{tabular}{|c|c|c|c|c|c|c|c|c|c|c|c|c|}
\hline & \multicolumn{4}{|c|}{ Dual-earner and liberal } & \multicolumn{4}{|c|}{ General family support } & \multicolumn{4}{|c|}{$\begin{array}{l}\text { Familialistic and } \\
\text { transition post socialist }\end{array}$} \\
\hline & DK & $\mathrm{N}$ & SW & UK & AT & FR & GER & $\mathrm{NE}$ & IT & ESP & $\mathrm{HU}$ & PL \\
\hline \multicolumn{13}{|l|}{ Men } \\
\hline Married, no children & $\begin{array}{l}++ \\
+\end{array}$ & + & ++ & + & + & + & + & ++ & + & & + & + \\
\hline Married, child & $\begin{array}{l}++ \\
+\end{array}$ & & + & & + & & & + & & & & \\
\hline Living alone & $\begin{array}{l}++ \\
+\end{array}$ & - & ++ & + & & & & -- & + & + & & + \\
\hline Son/daughter & $\begin{array}{l}++ \\
+\end{array}$ & & & +++ & ++ & + & + & & + & + & & \\
\hline $\begin{array}{l}\text { Cohabiting, no } \\
\text { children }\end{array}$ & $\begin{array}{l}++ \\
+\end{array}$ & & ++ & + & & & + & ++ & + & & - & + \\
\hline Cohabiting, children & $\begin{array}{l}++ \\
+\end{array}$ & + & + & & & & - & & & & - & \\
\hline Single parent & & -- & & + & ++ & & - & - & & - & - & + \\
\hline
\end{tabular}

Women

\begin{tabular}{l|l|l|l|l|l|l|l|l|l|l|l|l}
\hline Married, no children & ++ & + & + & ++ & +++ & + & + & ++ & ++ & + & + & + \\
\hline Married, child & + & + & & + & + & & & + & & & & \\
\hline Living alone & - & -- & -- & -- & -- & -- & -- & -- & - & - & -- & - \\
& & - & & - & - & & & - & & & - & \\
\hline $\begin{array}{l}\text { Son/daughter } \\
\begin{array}{l}\text { Cohabiting, no } \\
\text { children }\end{array}\end{array}$ & ++ & & & - & & & + & + & ++ & & - & - \\
\hline $\begin{array}{l}\text { Cohabiting, children } \\
\text { Single parent }\end{array}$ & -- & -- & -- & -- & -- & -- & -- & -- & -- & -- & -- & - \\
\hline
\end{tabular}

+ increases the odds ratio by an absolute value of $0.20-0.99 ;++$ increases the odds ratio by an absolute value of $1.00-1.99 ;+++$ increases the odds ratio by an absolute value of 2.0 and more

- decreases the odds ratio by an absolute value of $0.20-0.99$; -- decreases the odds ratio by an absolute value of $1.00-1.99$; --- decrease the odds ratio by an absolute value of 2.0 and more

the proportion of a certain household position in a country. Among men (Fig. 2), the correlation is indeed generally nil to negative, with the exception of men living alone. However, the negative trend is only significant for married men living without children. A change of one standard deviation in the proportion of this household position eliminates the disadvantage as compared to the married with two or more children. The result is similar for the cohabiting living without children, albeit not statistically significant. A strong positive but not significant correlation exists for men living alone, with a change of one standard deviation resulting in increasing disadvantage of 0.15 , e.g. from 0.40 to 0.55 , which is an increase in the odds ratio from 1.49 to 1.73 .

Among women (Fig. 3), trends are mixed and not significant with two important exceptions. First, cohabiting women clearly follow the institutionalization hypothesis: the more frequent this position, the less disadvantageous it is. This trend 

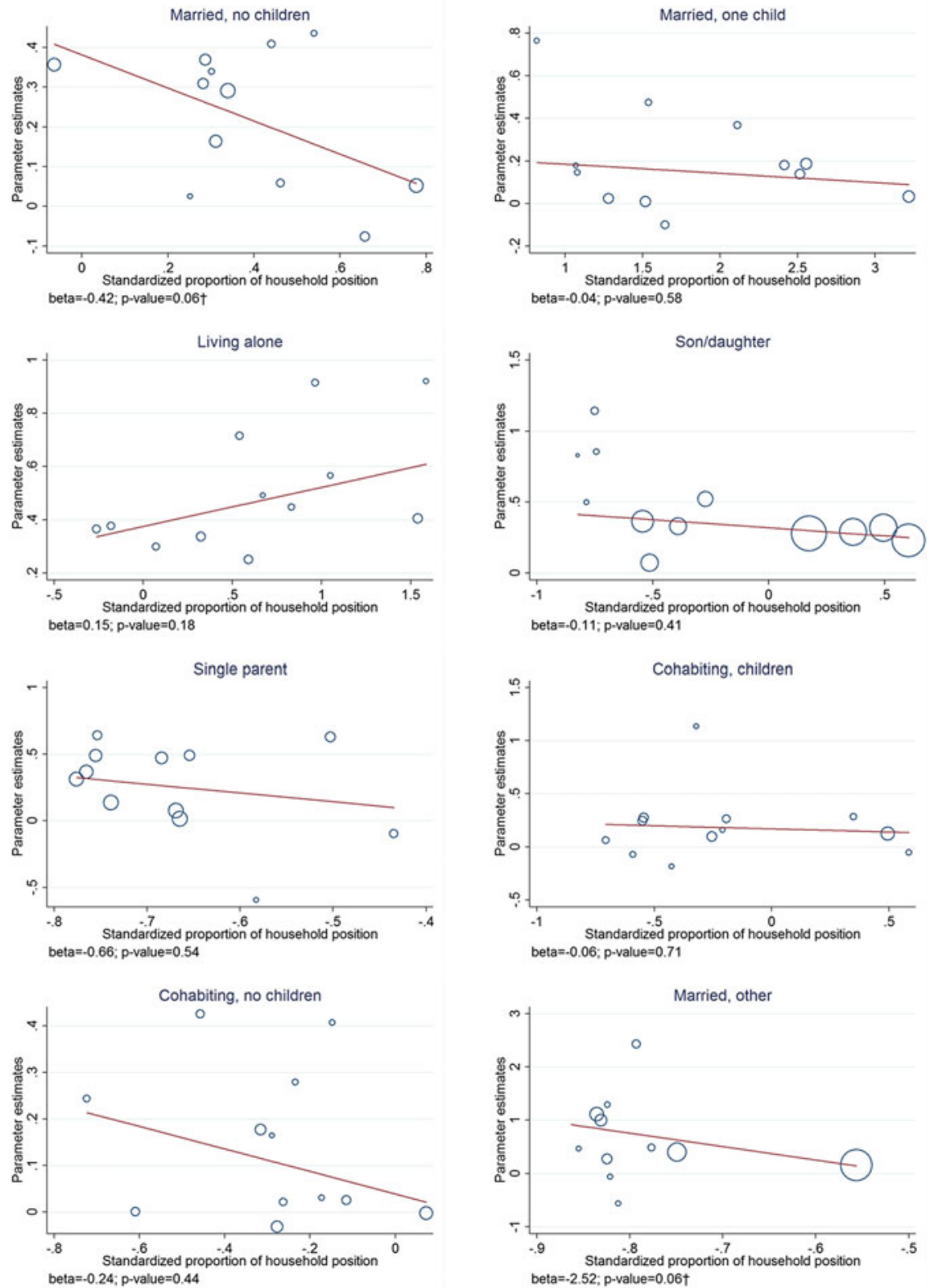

Fig. 2 Correlation between the standardized proportion of a certain household position and the parameter estimates of poor health [ln(odds ratios)] in comparison to the married with two or more children. Men. (Note: Circle size indicates the standard error of the estimate) 

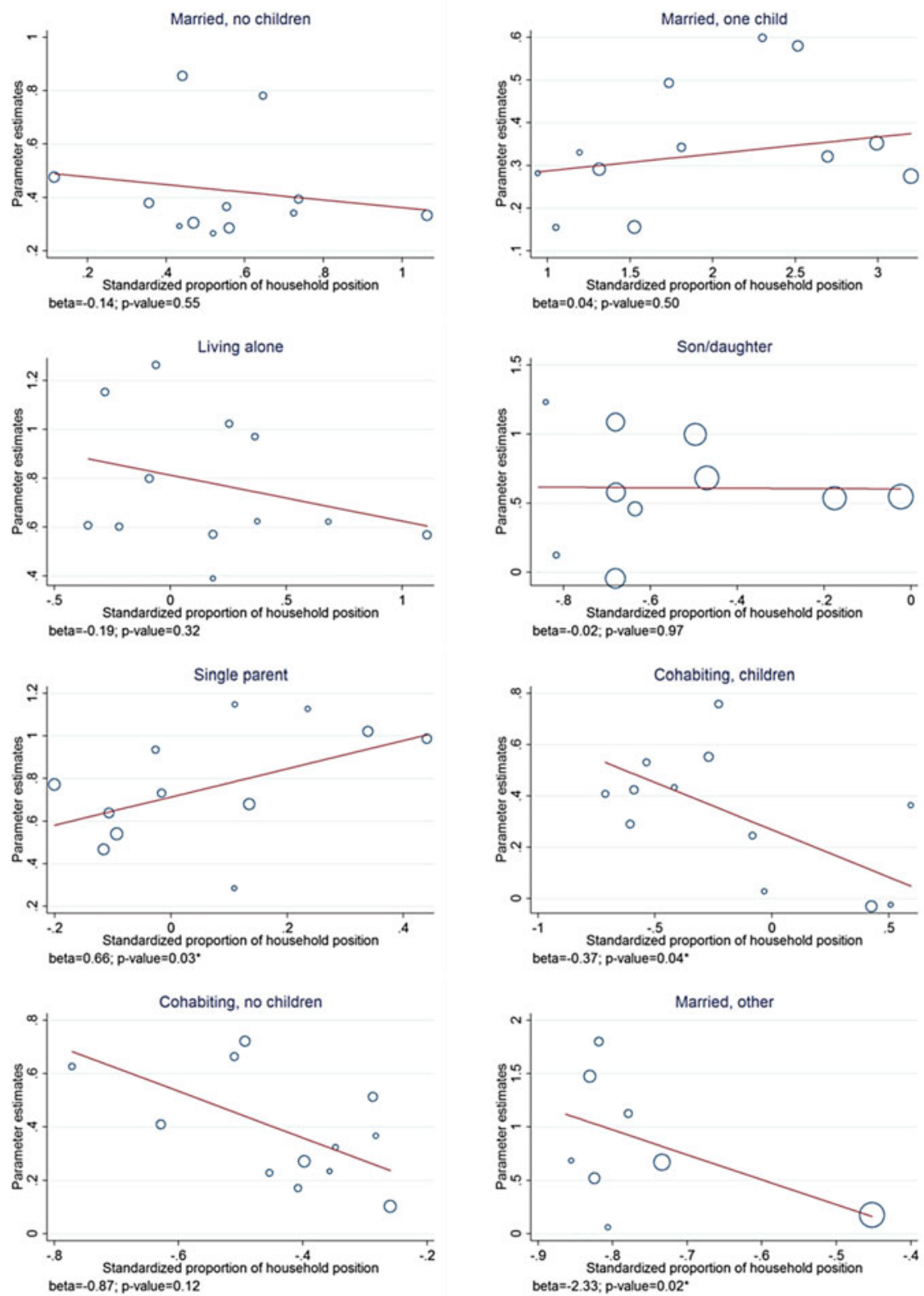

Fig. 3 Correlation between the standardized proportion of a certain household position and the parameter estimates of poor health [ln(odds ratios)] in comparison to the married with two or more children. Women. (Note: Circle size indicates the standard error of the estimate) 
is particularly obvious and highly significant for cohabiting women living with children, but also exists for those living without children. A change of one standard deviation in the proportion of this position reduces the disadvantage by 0.37 , i.e. reduces the odd ratio from 1.49 to 1.03 . Second, women living as single parents reveal a significant positive trend, which is contrary to the institutionalization hypothesis: The more frequent the position, the more disadvantageous it is. An increase of one standard deviation increases the disadvantage by 0.66 , resulting in an odds ratio of 2.89 instead of 1.49 .

\section{Discussion}

The composition of the household has large repercussions for the health of an individual. This is true in addition to individual characteristics. We not only show the extent of these repercussions but also present evidence that they depend on the value climate in a society.

We defined household position by the presence of a partner and/or children as well as by being married or living in a consensual union. First, we considered the effect of the household position on health, testing the three hypotheses that the married fare best, that household position matters more for women than for men, and that some of the differentials can be explained by financial deprivation. We find large health differentials by household position and regardless of sex, married individuals with two and more children fare best, single mothers and those living alone fare worst. Differences tend to be larger and statistically highly significant among women, with the exception of the Dual-Earner countries. Our results show that financial deprivation accounts for some of the disadvantage of single mothers but not for all. This is also true for women living alone. The reverse, a better economic situation as well as the economies-of-scale advantage, may explain some of the better health of the married.

A large number of studies shows that the number of children ever born exerts a small but important effect on the health of women and partly also of men late in life, with two to three children being associated with the best health outcome (see Tomassini, Di Gessa, and Egidi, and Hank and Steinbach in this book). Our study shows that even at young and middle ages, the health of married parents is associated with the number of children in the household and that one child, and in particular no children in the household is associated with worse health outcomes. This is remarkable insofar as in our cross-sectional data those living without children or with one child might have once constituted a multi-child family during their life course. Indeed, the category living without children comprises childless persons whose worse health outcome has been repeatedly shown (see Hank and Steinbach in this volume) and parents whose children have already moved out of the household. When interpreting our results one has to be careful by taking into account the heterogeneity within the categories and the possibility of a changing effect of children on the health of their parents. For example, recent studies of 
happiness (Myrskylä and Margolis 2014) suggest that happiness increases prior to and in the year of having a child and decreases thereafter, with individuals who became parents at young ages having a downward happiness trajectory, while those becoming parents at older ages have a higher happiness level after the birth. The first child tends to increase happiness, the second much less, and the third may decrease happiness. This heterogeneous effect of children on happiness may also be present in terms of subjective health.

However, there are considerable differences in the association between household position and health by the welfare state regime and even by countries belonging to one regime. To further explore the country-differences we tested the institutionalization hypothesis.

The institutionalization hypothesis states that in countries where a certain partnership form is more common and thus probably more accepted, the disadvantage compared to the married is smaller. Soons and Kalmijn (2009) developed this hypothesis to study the cohabitation gap in wellbeing as compared to the married; we extended this concept to all household positions. We found strong support for the hypothesis for women living in consensual unions and for married men without children. Regarding cohabitation, both sexes face higher odds of poor health when cohabiting, and the lower the proportion living in such a partnership form, the higher the disadvantage as compared to the married living with children. The trend is even more pronounced when children are not present in the household; however, it is only statistically significant among women with children. No comparable trend exists among cohabiting men. In their study on well-being in 30 European countries, Soons and Kalmijn found that about one third of the difference of the cohabitation gap can be explained by differences in the composition between cohabiting and married people with employment, with education and religiosity playing important roles. Cohabiting people are less likely to be employed and religious and are thus less happy. A similar argument could be made for our study. We control for employment and education but not for religiosity, while it is well know that religious people have better health and live longer (e.g. Powell et al. 2003; Rew and Wong 2006). We also control for financial deprivation which, however, does not have much effect on the cohabitation gap.

Following Soons and Kalmijn (2009), the size of the cohabitation gap might be explained by the normative approval/disapproval of consensual unions, as well as the general value climate in a society ranging from traditional to (post)modern. Because the value climate is usually gendered, it is no surprise that it affects women more than men, an aspect which was not studied by the two authors.

An unexpected result is that married men living without children follow the institutionalization hypothesis but women do not. Here longitudinal data or retrospective information might help in untangling this heterogeneous group into the married childless, the married whose children have moved out, and the re-married whose children live with the former wife. Indeed, the latter is the only group where men and women differ, with re-married women usually living with the children from the previous marriage (and therefore not belonging to the group married without children). The trend might thus be an indirect indication that in societies 
where divorce and re-marriage is more accepted, the disadvantage to health is smaller. This, however, needs to be confirmed in future studies.

To our surprise single mothers do not follow the institutionalization hypothesis; the trend is just the opposite: The more common single mothers in a country are, the higher their health disadvantage. Some of this can be explained by financial deprivation, which is generally worse for them compared to the married, however, a sizeable effect still remains, particularly in the Scandinavian countries. One possible explanation is the distribution of unpaid work, which is more gender equal in these countries. Single mothers there may not only face financial problems but also forgo the partner as an important resource in dividing unpaid work. We will return to this below.

Another household position that does not follow the institutionalization hypothesis is living alone for men. While for women the hypothesis holds true, men face the highest disadvantage in Denmark, Sweden, and Germany, where the proportion is highest, and the lowest in the TPS and Familialistic countries, where the proportion is lowest. Financial deprivation explains much of the disadvantaged health situation in the first group of countries, little in the latter. One explanation might be that the social composition of those living alone differs between the countries. In the TPS and Familialistic countries, those facing financial difficulties might have moved back to their parental home. In these countries more than ten percent live as an adult son in the parental home; in the other countries they might stay on their own. This explanation is supported by the fact that in the Nordic countries the disadvantage is attenuated and loses significance when financial deprivation is controlled for, while there is no to little change in the Familialistic and TPS countries. Further support comes from a study by Ahn and Sánchez-Marcos (2015), who found that in Spain the proportion living alone increased during the financial crises (2009-2013) as compared to the boom years before, and that this rise was mainly driven by the full-time employed.

This study is based on cross-sectional data. Future studies on the relationship between household position and health would certainly benefit from life-course data that permit the study of both prior and current household positions. For example, in many countries cohabitation is still assumed to be a transitory phase before marriage. Marriage is perceived as a higher level of commitment and cohabitation is perceived as a testing period which is subordinated to the marriage ideal (Perelli-Harris et al. 2014). There are very different trajectories between cohabitation, marriage, and childbirth in the different European countries (Kok and Leinarte 2016) and thus far there appears to be no convergence of European life courses (Billari and Wilson 2001).

In testing the institutionalization hypothesis, we used the proportion of people living in a specific type of living arrangement as a proxy for the value climate. This hinges on the assumption that family forms are predominantly an outcome of the value structure of a society; however, there are also other determinants that influence the likelihood of family forms, such as the welfare system, the economic situation, etc. A fruitful approach for future studies might thus be to use a more direct measure of the value climate, as did Soons and Kalmijn (2009) when they 
explored the perceived attitude towards cohabitation in relation to well-being. Another approach might be to explore historical patterns of cohabitation, as was done by Klüsener (2016), who used these as a proxy for attitudes that are shaped by traditions of the past. In his study of extramarital births in Europe, Klüsener showed that continuity is still visible, albeit fading.

\section{Conclusion}

With the Second Demographic Transition living arrangements and household forms became more diverse, yet there seems to be no convergence to a predominantly European model. Our study shows that in Europe the household is an influential factor of health; this is particularly true for women but it is also important for men. There seem to be general patterns of advantaged and disadvantaged positions which however, are strongly modifiable. The general value climate in a society and the support by the welfare state determine to what extent certain household forms are beneficial or detrimental to health. Therefore, differences in recent evolution of family patterns across Western countries seem to influence the magnitude of the association of family with health differently, drawing a heterogeneous European map. Future country studies of living arrangement and health have to take this heterogeneity into account.

\section{References}

Ahn, N., \& Sánchez-Marcos, V. (2015). Emancipation under the great recession in Spain. Review of economics of the household. https://doi.org/10.1007/s11150-015-9316-7.

Artazcoz, L., Borrell, C., \& Benach, J. (2001). Gender inequalities in health among workers: the relation with family demands. Journal of Epidemiology and Community Health, 55(9), 639647.

Barnett, R. C., \& Hyde, J. S. (2001). Women, men, work, and family. American Psychologist, 56(10), 781-796. https://doi.org/10.1037//0003-066X.56.10.781.

Bartlett, E. E. (2004). The effects of fatherhood on the health of men. A review of the literature. The Journal of Men's Health \& Gender, 1(2-3), 159-169. https://doi.org/10.1016/j.jmhg.2004. 06.004 .

Bernstein, A. B. (2001). Motherhood, health status, and health care. Women's Health Issues, 11(3), 173-184. https://doi.org/10.1016/S1049-3867(01)00078-0.

Billari, F. C., \& Liefbroer, A. C. (2010). Towards a new pattern of transition to adulthood? Advances in Life Course Research, 15(2-3), 59-75. https://doi.org/10.1016/j.alcr.2010.10.003.

Billari, F. C., \& Wilson, C. (2001). Convergence towards diversity? Cohort dynamics in the transition to adulthood in contemporary Western Europe. In Max Planck Institute for Demographic Research Rostock, Working Paper No. 2001-039.

Boje, T.P. (2007): Welfare and work. The gendered organisation of work and care in different European Countries. European Review, 15(03), 373. https://doi.org/10.1017/S1062798707000361. 
Brockmann, H., \& Klein, T. (2004). Love and death in Germany. The marital biography and its effect on mortality. Journal of Marriage and Family, 66(3), 567-581. https://doi.org/10.1111/j. 0022-2445.2004.00038.x.

Cherlin, A. J. (2000): Toward a new home socioeconomics of union formation. In: L. J. Waite \& C. Bachrach (Hg.) (Eds.), The ties that bind. Perspectives on marriage and cohabitation (pp. 126-144). New York: Aldine de Gruyter (Social institutions and social change).

Cooke, L. P., \& Gash, V. (2010). Wives' part-time employment and marital stability in Great Britain, West Germany and the United States. Sociology, 44(6), 1091-1108. https://doi.org/10. 1177/0038038510381605.

Demakakos, P., Nazroo, J., Breeze, E., \& Marmot, M. (2008). Socioeconomic status and health. The role of subjective social status. Social Science and Medicine, 67(2), 330-340. https://doi. org/10.1016/j.socscimed.2008.03.038.

Esping-Andersen, G. (1998). The three worlds of welfare capitalism. Princeton, N.J: Princeton University Press. Online verfügbar unter http://www.loc.gov/catdir/description/prin021/ 89024254.html.

Eurostat (2016). Being young in Europe today. http://ec.europa.eu/eurostat/statistics-explained/ index.php/Being_young_in_Europe_today_-_family_and_society. Accessed 15 March 2016.

FamilyAndSocieties. http://www.familiesandsocieties.eu/.

Floderus, B., Hagman, M., Aronsson, G., Marklund, S., \& Wikman, A. (2008). Self-Reported health in mothers. The impact of age, and socioeconomic conditions. Women and Health, 47(2), 63-86. https://doi.org/10.1080/03630240802092308.

Gahler, M. (2006). "To divorce is to die a bit...". A longitudinal study of marital disruption and psychological distress among Swedish women and men. The Family Journal, 14(4), 372-382. https://doi.org/10.1177/1066480706290145.

Gumà, J., \& Cámara, A. D. (2014). ¿Informa la salud autopercibida sobre las condiciones objetivas de salud? Algunas conclusiones a partir del análisis demográfico de microdatos de la Encuesta Nacional de Salud. Revista de Estadística Española, 56(183), 61-76.

Helbig, S., Lampert, T., Klose, M., \& Jacobi, F. (2006). Is parenthood associated with mental health? Findings from an epidemiological community survey. Social Psychiatry and Psychiatric Epidemiology, 41(11), 889-896. https://doi.org/10.1007/s00127-006-0113-8.

Hobson, B., \& Olah, L. S. (2006). Birthstrikes? Agency and capabilities in the reconciliation of employment and family. Marriage \& Family Review, 39(3-4), 197-227. https://doi.org/10. 1300/J002v39n03_01.

Hofäcker, D., \& Chaloupková, J. (2014). Patterns of family life courses in Europe-between standardisation and diversity A cross-national comparison of family trajectories and life course norms in European countries. Hg. v. Federal Institute for Population Research.

Hughes, M. E., \& Waite, L. J. (2002). Health in household context: Living arrangements and health in late middle age. Journal of Health and Social Behavior, 43(1), 1-21.

Hughes, M. E., \& Waite, L. J. (2009). Marital biography and health at mid-life. Journal of Health and Social Behavior, 50(3), 344-358. https://doi.org/10.1177/002214650905000307.

Idler, E. L., \& Benyamini, Y. (1997). Self-rated health and mortality. A review of twenty-seven community studies. Journal of Health and Social Behavior, 38(1), 21-37. https://doi.org/10. $2307 / 2955359$.

Klüsener, S. (2016). Spatial variation in non-marital fertility across Europe in the twentieth and twenty-first centuries. Recent trends, persistence of the past, and potential future pathways. The History of the Family, 20(4), 593-628. https://doi.org/10.1080/1081602X.2015.1099112.

Kok, J., \& Leinarte, D. (2016). Cohabitation in Europe. A revenge of history? The History of the Family, 20(4), 489-514. https://doi.org/10.1080/1081602X.2015.1067240.

Lesthaege, R. (1995). The second demographic transition in Western countries: An interpretation. In: K. O. Mason \& A.-M. Jensen (Hg.) (Eds.) Gender and family change in industrialized countries, (pp. 17-62). Oxford: Clarendon Press (International studies in demography).

Liefbroer, A., \& Fokkema, T. (2008). Recent trends in demographic attitudes and behaviour: Is the second demographic transition moving to southern and eastern Europe? In J. Surkyn \& 
P. Deboosere (Hg.) (Eds.), Demographic challenges for the 21st century: A state of the art in demography (pp. 115-142). Brussels: VUB Press.

Liefbroer, A., \& Merz, E.-M. (2009). Report on analysis of ESS data on cross-national differences in perceived norms concerning fertility-related behaviour. REPRO deliverable, 16(6).

Lillard, L., \& Panis, C. W. A. (1996). Marital status and mortality: The role of health. Demography, 33(3), 313-327.

Lillard, Lee A., \& Waite, Linda J. (1995). Til death do us part: Marital disruption and mortality. American Journal of Sociology, 100(5), 1131-1156. https://doi.org/10.1086/230634.

Marmot, M., \& Wilkinson, R. G. (Eds.). (1999). Social determinants of health. Oxford: Oxford University Press.

Martikainen, P., Martelin, T., Nihtilä, E., Majamaa, K., \& Koskinen, S. (2005). Differences in mortality by marital status in Finland from 1976 to 2000. Analyses of changes in marital-status distributions, socio-demographic and household composition, and cause of death. Population Studies, 59(1), 99-115. https://doi.org/10.1080/0032472052000332737.

McDonald, P. (2000). Gender equity, social institutions and the future of fertility. Journal of Population Research, 17(1), 1-16. https://doi.org/10.1007/BF03029445.

Myrskylä, M., \& Margolis, R. (2014). Happiness. Before and after the kids. Demography, 51(5), 1843-1866. https://doi.org/10.1007/s13524-014-0321-x.

Neyer, G. (2013). Welfare states, family policies, and fertility in Europe. In: G. Neyer, G. Andersson, H. Kulu, L. Bernardi, \& C. Bühler (Hg.) (Eds.), The Demography of Europe (pp. 29-53). Dordrecht: Springer.

Nock, S. L. (1995). A comparison of marriages and cohabiting relationships. Journal of Family Issues, 16(1), 53-76.

OECD. (2012). Closing the gender gap. Act now. Paris: OECD. Online verfügbar unter http:// www.gbv.de/dms/zbw/73244778X.pdf.

OECD. (2016a). Pensions at a glance. www.oecd.org/pensions/pensionsataglance.htm. Accessed 15 March 2016.

OECD. (2016b). OECD. Stat. Full-time equivalent employment rate. Online verfügbar unter http:// stats.oecd.org/index.aspx?queryid $=54749$.

Perelli-Harris, B., Berrington, A., Berghammer, C., Keizer, R., Lappegård, T., Mynarska, M., \& et al. (2014). Towards a new understanding of cohabitation. Demographic Research 31, 10431078. https://doi.org/10.4054/DemRes.2014.31.34.

Powell, L. H., Shahabi, L., \& Thoresen, C. E. (2003). Religion and spirituality. Linkages to physical health. American Psychologist, 58(1), 36-52. https://doi.org/10.1037/0003-066X.58. 1.36 .

Puur, A., Oláh, L. S., Tazi-Preve, M. I., Dorbritz, J. (2008). Men's childbearing desires and views of the male role in Europe at the dawn of the 21st century. Demographic Research 19, 18831912. https://doi.org/10.4054/DemRes.2008.19.56.

Rew, L., \& Wong, Y. J. (2006). A systematic review of associations among religiosity/spirituality and adolescent health attitudes and behaviors. Journal of Adolescent Health, 38(4), 433-442. https://doi.org/10.1016/j.jadohealth.2005.02.004.

Rotermann, M. (2007). Marital breakdown and subsequent depression. Health Reports, 18(2), $33-44$.

Sayer, L. C., \& Bianchi, S. M. (2000). Women's economic independence and the probability of divorce. A review and reexamination. Journal of Family Issues, 21(7), 906-943. https://doi. org/10.1177/019251300021007005.

Soons, J. P. M., \& Kalmijn, M. (2009). Is marriage more than cohabitation? Well-being differences in 30 European countries. Journal of Marriage and Family, 71(5), 1141-1157. https://doi.org/ 10.1111/j.1741-3737.2009.00660.x.

Stevenson, B., \& Wolfers, J. (2007): Marriage and divorce: Changes and their driving forces. Institute for the Study of Labor (2602). 
Surkyn, J., \& Lesthaeghe, R. (2004): Value orientations and the second demographic transition (SDT) in Northern, Western and Southern Europe. An Update. Demographic Research (3), 45-86. https://doi.org/10.4054/DemRes.2004.S3.3.

van de Kaa, D. J. (1994). The second demographic transition revisited: Theories and expectations. In: G. Beets, H. van Den Brekel, R. L. Cliquet, G. Dooghe, \& J. de Jong Gierveld (Hg.) (Eds.), Population and family in the Low Countries 1993: Late fertility and other current issues (pp. 81-126). Berwyn, Pennsylvania, Amsterdam: Swets and Zeitlinger.

Vincent-Lancrin, S. (2008): The reversal of gender inequalities in higher education. In: Demography (Vol. 1, pp. 265-298). Paris: OECD (Higher education to 2030).

Waite, L. J. (1995). Does marriage matter? Demography, 32(4), 483-507.

Waldron, I., Weiss, C. C., \& Hughes, M. E. (1997). Marital status effects on health: are there differences between never married women and divorced and separated women? Social Science and Medicine, 45(9), 1387-1397.

Wang, J. L. (2004). The difference between single and married mothers in the 12-month prevalence of major depressive syndrome, associated factors and mental health service utilization. Social Psychiatry and Psychiatric Epidemiology, 39(1), 29-42.

Williams, K., \& Umberson, D. (2004). Marital status, marital transitions, and health. A Gendered Life Course Perspective. Journal of Health and Social Behavior, 45(1), 81-98. https://doi.org/ $10.1177 / 002214650404500106$.

World Health Organization (WHO). (1946). In minutes of the technical preparatory committee for the international health conference (pp. 03-18).

Open Access This chapter is licensed under the terms of the Creative Commons Attribution 4.0 International License (http://creativecommons.org/licenses/by/4.0/), which permits use, sharing, adaptation, distribution and reproduction in any medium or format, as long as you give appropriate credit to the original author(s) and the source, provide a link to the Creative Commons license and indicate if changes were made.

The images or other third party material in this chapter are included in the chapter's Creative Commons license, unless indicated otherwise in a credit line to the material. If material is not included in the chapter's Creative Commons license and your intended use is not permitted by statutory regulation or exceeds the permitted use, you will need to obtain permission directly from the copyright holder.

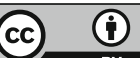

